\title{
Stress testing geomorphic and traditional tailings dam designs for closure using a landscape evolution model
}

\author{
N Slingerland University of Alberta, Canada \\ NA Beier University of Alberta, Canada \\ GW Wilson University of Alberta, Canada
}

\begin{abstract}
The design of tailings dams with respect to closure has evolved over the last 50 years; however, their longterm erosion continues to be a challenge. Erosion is a well-known and established failure mode with several high-profile incidents at hydro-electric dams in recent history, such as the Oroville, California (2017) and Archusa Creek, Michigan (1998) dams. The goal of tailings dam closure and reclamation is often to create a 'walk-away' state: an impediment to achieving this is long-term erosion. Various design strategies have been employed as alternatives to uniform downstream dam slopes that are erosion-prone due to the long and steep flow paths generated. This study used the CAESAR-Lisflood landscape evolution model to stress test five different dam designs using Alberta oil sands climate and material inputs. The fictional dam designs included a traditional uniform slope, a platform-bank slope, a catena or 's-curve' slope, an alternating uniform-tocatena slope, and an alternating uniform-to-catena slope with armouring along the central channel. Stress testing allowed for efficient comparative assessment of the long-term geomorphic stability of the designs, and a method of quantifying dam performance for cost-benefit analysis. Results indicated that more natural slopes performed better than those uncommon in nature, and that mobile channel base sediment was more beneficial than a rigid (armoured) base. This has implications for long-term cost-benefit analyses for tailings dam construction and maintenance.
\end{abstract}

Keywords: dam design, erosion, geomorphology, landscape evolution model, mine closure, sustainability

\section{$1 \quad$ Introduction}

Tailings dams are one of the first structures built on a mine site and are one of few that will remain long after mining has ceased. Constructed of coarse tailings and/or overburden waste, these dams are raised slowly as liquid mine waste, or 'tailings', are deposited on their upstream side. Tailings can be chemically reactive, have elevated levels of metals, and/or contaminated porewater; consequently, the closure and reclamation of these dams and their retained tailings (collectively referred to as a tailings storage facility, or TSF) is imperative from environmental, social, and economic perspectives.

Following their 'active life' of tailings deposition, TSF's are expected to be converted to a solid earthen structure (Oil Sands Tailings Dam Delicensing Committee 2014) and reclaimed. Reclamation is expected to take place to the extent that the structure behaves similarly to natural, undisturbed terrain; this means that maintenance and risks associated with the tailings 'landform' are equivalent to that of local naturally-formed landforms. Current practice on many mine sites includes the construction of dam slopes with either uniform slopes, or a series of uniform slopes broken up with benches (known as the 'platform-bank' approach). These types of slopes are not found in nature, therefore it is reasonable to question their longevity and ability to perform similarly to naturally-derived slopes.

Wind, water, and gravity alter the landscape through erosion and weathering over time. The resulting alterations are reflective of local climate, construction materials and surficial soils, vegetation, and management practices. These processes and interactions are not typically detrimental to natural, undisturbed terrain or hydrologic systems, but when they occur on a tailings dam, the reclamation works 
could be compromised. Erosion has been identified as a long-term reclamation challenge for tailings dams, particularly when caps and covers are essential to reclamation performance (Rowell 1977; McKenna \& Dawson 1997). Failure of mine waste structures due to erosion has been well documented (Haig 1979; Hancock \& Willgoose 2004; Sawatsky et al. 2000). An ideal closure design with respect to long-term erosion reduction and therefore geomorphic stability, would take these factors into consideration to a degree that the dam is as geomorphically 'mature' as possible when reclamation is completed.

Until recently, the relative erodibility of sand-constructed tailings dams and long-term erosion potential had been noted (McKenna \& Dawson 1997; Rowell 1977), but the cumulative long-term ramifications of this could only be hypothesized. Various forms of the empirical Universal Soil Loss Equation (USLE) have been capable of providing annual soil loss from a dam slope due to rill and inter-rill processes, but no spatial or temporal information was available without field-scale construction of slopes and subsequent long-term measurement. Closed and reclaimed TSFs have been monitored and actively maintained, but few to date have achieved reclamation certification (McKenna \& Dawson 1997). Modern landscape evolution models (LEMs), such as 'SIBERIA' and 'CAESAR-Lisflood' provide a tool to simulate erosion and deposition as a result of fluvial processes and site-specific substrate and climate conditions, so that predictions can be made.

LEMs have been used extensively to assess the long-term geomorphology of post-mining landscapes, particularly for waste rock dumps (Hancock et al. 2000, 2003, 2008a, 2008b, 2019; Lowry et al. 2013, 2019) and to some degree for tailings dams (Hancock \& Willgoose 2004; Hancock et al. 2008a; Slingerland et al. 2018a). In the present application of CAESAR-Lisflood to theoretical and experimental tailings dam slopes, stress testing is conducted using an extreme climate in order to determine which dam slopes perform best.

Previous application of the CAESAR-Lisflood LEM has confirmed short- to medium-term field observations on sand-constructed tailings dams in the Alberta oil sands, including a tendency for large gullies to develop, and for erosion to persist over long time frames (Slingerland et al. 2018a, 2018b). Erosional features have been measured in the field on downstream dam slopes with less than a $5 \%$ gradient, producing final post-erosion dam slopes with gradients less than $1 \%$ (Slingerland et al. 2018c). This suggests that even if space existed onsite to flatten downstream dam slopes, or if larger TSF footprints were permitted such that shallower slopes were generated, there is no reasonable minimum slope for which erosion would cease to occur on a sand tailings dam. These approaches have historically been deemed innovative as they consider long-term performance in addition to short-term efficiency.

Geomorphic design of mining-affected landscapes was first introduced by the United States' Surface Mining Control and Reclamation Act (SMCRA) in 1977 as a requirement to return mined land to the approximate original contour (SMCRA 1977). Toy \& Hadley (1987), Sawatsky \& Beckstead (1996), and others, identified deficiencies in the standard practice of constructing uniform slopes, and instead recommended a geomorphic approach for mined land reclamation. Of particular importance is that uniform slopes include no 'self-healing' mechanism, such that ongoing maintenance is often required (Sawatsky \& Beckstead 1996). At its core, the geomorphic design approach seeks to generate a more sustainable landscape that compliments the surrounding topography and drainage systems, and seamlessly integrates the reclaimed land. At a minimum, this typically includes shallow, undulating topography and complex slopes that form an 's-curve' whereby lower concave slope is elongated (Hancock et al. 2003) (Figure 1). More recently the approach has been further investigated (DePriest et al. 2015; Eckels \& Bugosh 2010; Kemp et al. 2016; Martin-Duque et al. 2010; Nicolau 2003; Sawatsky \& Beersing 2014; Toy \& Chuse 2005; Toy \& Black 2000; Toy \& Hadley 1987), but it has not yet become commonplace on TSFs, despite the described benefits. 


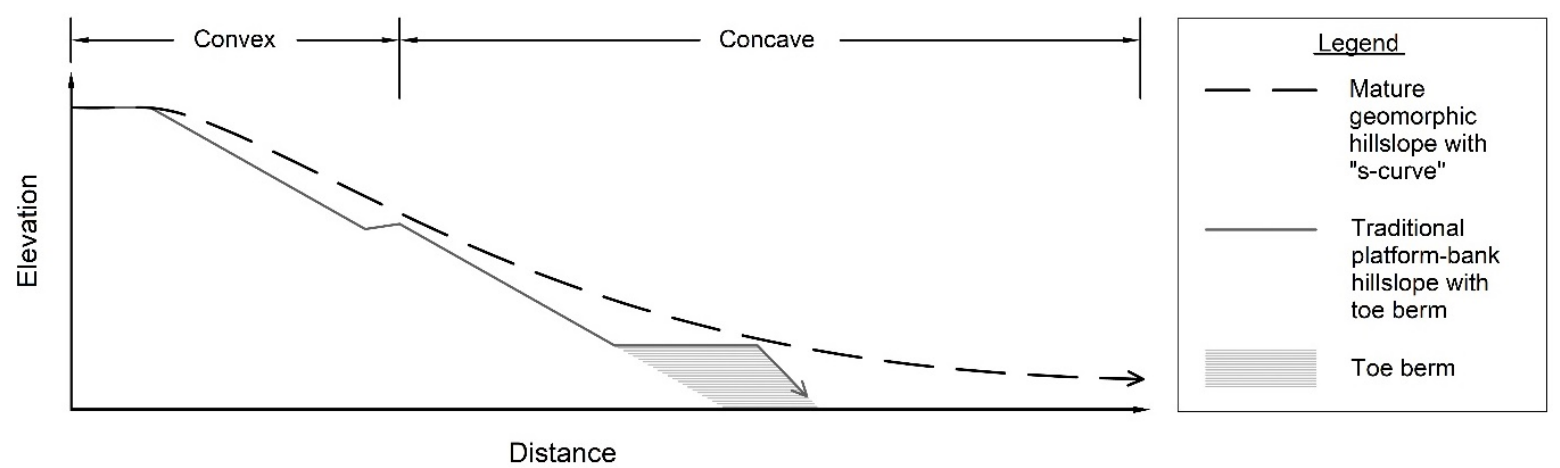

Figure 1 Traditional platform-bank dam slope in comparison to a geomorphic 's-curve' slope (from Slingerland et al. 2019)

In the Athabasca oil sands (AOS), the region for which this study was primarily conducted (Figure 2), TSFs are frequently located adjacent to lease boundaries and occasionally environmental right-of-ways. During reclamation, dam slopes receive surficial soil amendments and vegetation planting, but their topography remains unaltered from initial (roughly) uniform-slope construction, primarily due to spatial constraints and the high cost of earth moving on a large-scale. The geomorphic approach outlined by Sawatsky \& Beckstead (1996) has been generally adopted for flattened areas within the AOS post-mining landscape, such as the central plateau of TSFs, with the exception that channel bottoms continue to be lined with rip-rap. It is now of interest how the geomorphic approach might be applied to the tailings dams themselves.

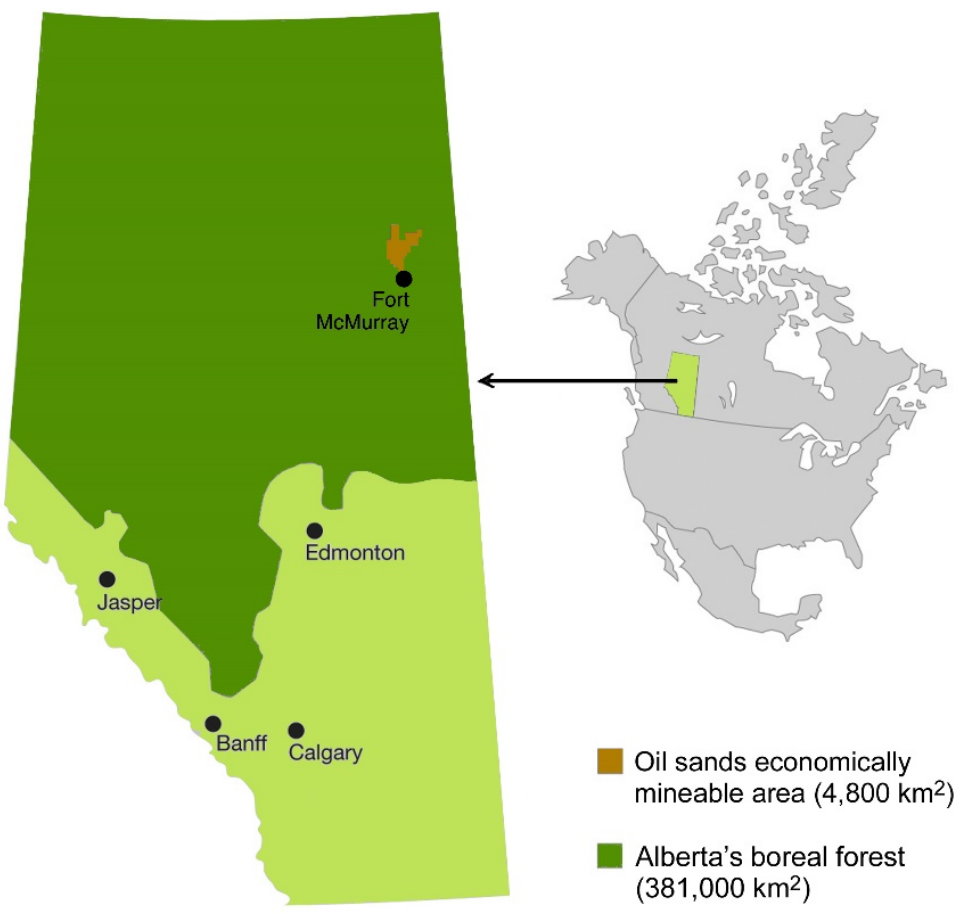

Figure 2 Location of the Alberta oil sands within North America (from Slingerland et al. 2019)

It has been well documented that an ' $s$ '-shape, or catena, slope will generate less erosion than a traditional uniform or platform-bank slope (Hancock et al. 2003; Toy \& Hadley 1987); however, altering the cross-section laterally such that flow is directed has not yet been investigated until now. Given the capabilities of LEMs, it is now possible to test a range of designs for erosion potential prior to construction. This research seeks to determine which downstream dam slope shape - traditional varieties, catena, or otherwise - is likely to provide the greatest erosion resistance over long time frames. 


\section{$2 \quad$ Methodology}

\subsection{Dam design scenarios}

Traditional tailings dam designs (including uniform slope and platform-bank slopes) and alternative tailings dam designs (including a catena slope, an alternating uniform-to-catena slope, and the later with armour mimicked along the central channel) are subjected to stress testing using the CAESAR-Lisflood LEM (Coulthard 2017). All fictional designs were assumed to be located in the AOS and to have a grain size distribution typical of oil sands coarse sand tailings (CST) as previously described by (Slingerland et al. 2018c). The designs each had an identical $40 \mathrm{~m}$ wide drainage ditch at the base of the dam, and a $25 \mathrm{~m}$ wide plateau at the top, such that the total length and height of all dam designs were the same. The dam core was modelled as CST from the channel base elevation to the full $60 \mathrm{~m}$ height, except in the case of the armoured design that has an erosion-resistant strip down the middle. Dam designs are illustrated in section in Figure 3.

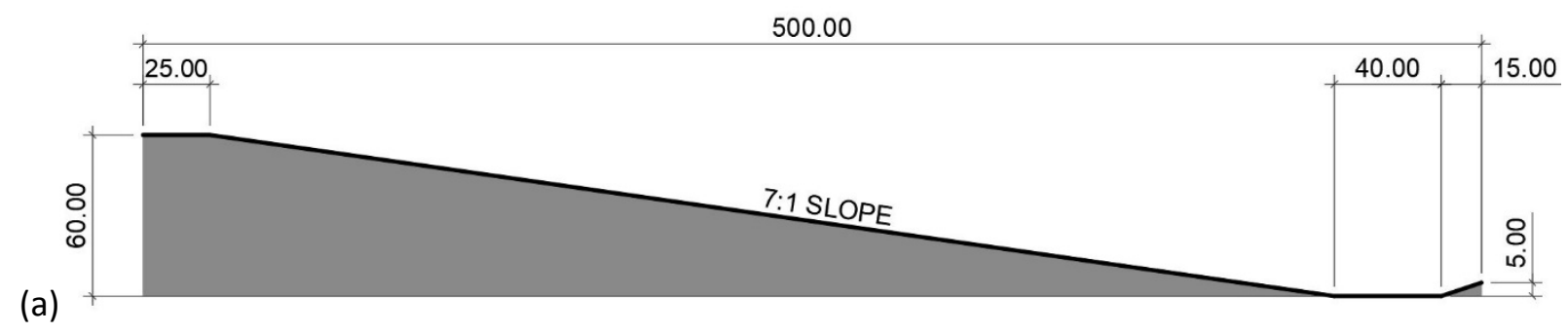

(a)

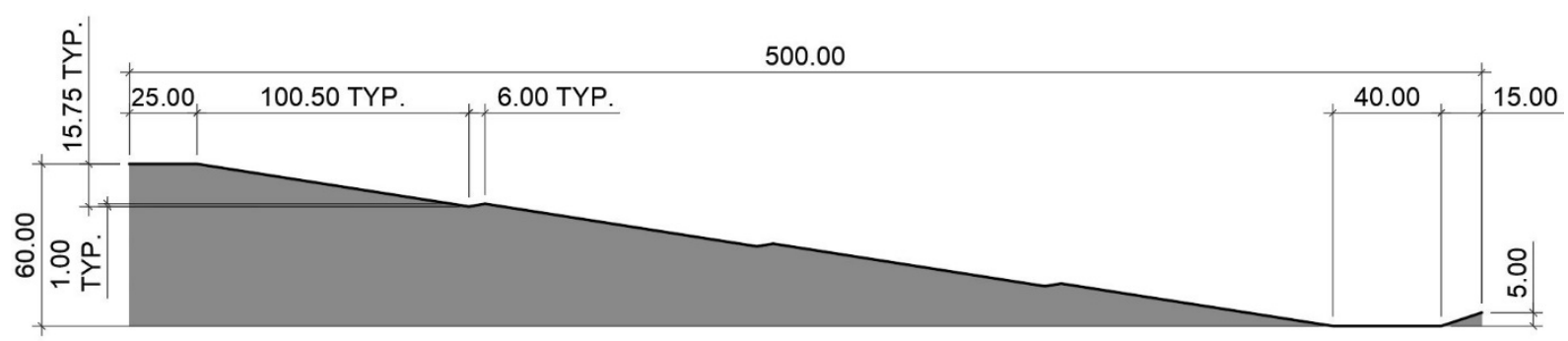

(b)

500.00

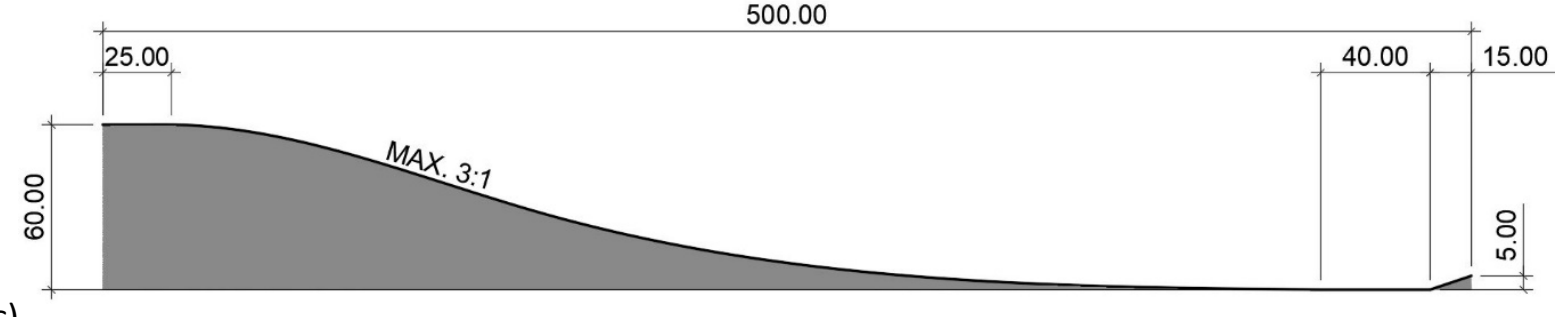

(c)

500.00

(d)

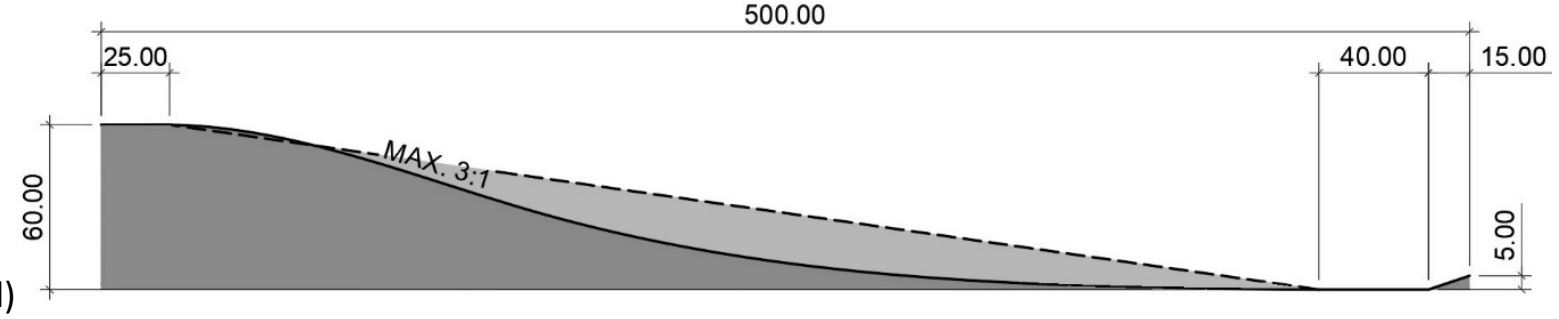

Figure 3 Dam designs subjected to stress testing in section; (a) constant slope, (b) platform-bank, (c) catena, and (d) directed flow (unarmoured and armoured). Note both the 'directed flow' designs have the same surficial topography with the dashed line representing the edges and solid line representing the centreline

The 'constant slope' design was considered as a base case, having a uniform 7:1 slope from top to bottom. The cross-section is universal across the $500 \mathrm{~m}$ width. 
The 'platform-bank' design was originally conceived as a method of dividing one long constant slope (as above) into several shorter slopes to reduce erosion and transport of soil offsite. This design has the same overall dimensions but is broken up by several $6 \mathrm{~m}$ benches tilted back into the dam. This design also has a universal cross-section across the $500 \mathrm{~m}$ width.

The 'catena' design is a more geomorphically mature geometry relative to the first two designs, similar to what many landforms will naturally progress to when dominated by fluvial erosion processes. A number of factors are responsible for this shape not being used in dam design, including software constraints for design and modelling as well as difficulty in constructing such a form. Given present day technologies and GPSguidance for heavy equipment, these types of rounded landforms are becoming more easily designed and constructed. The elongated ' $s$ '-shaped cross-section is universal across the $500 \mathrm{~m}$ width.

The 'directed flow' designs both have the same surficial topography: at either side of the $500 \mathrm{~m}$ dam a constant slope design is applied, but transitions to a catena topography in the centre. The result is a horseshoe or large swale-like form that directs drainage down the centre. The armoured version of this design also includes a $50 \mathrm{~m}$ central span of erosion resistance at the surface in order to mimic the erosion resistance provided by armouring. Armouring of drainage pathways is a common approach proposed to limit erosion.

\subsection{Landscape evolution modelling and assessment}

\subsubsection{CAESAR-Lisflood}

The CAESAR-Lisflood morphodynamic model (Coulthard 2017) was used to stress test the dam designs using a series of simulated extreme precipitation events. CAESAR-Lisflood is a landscape evolution model that simulates erosion, transport, and deposition of soil across nine grain size fractions, in three dimensions, and over time frames from hours to over 10,000 years. Model inputs include an hourly precipitation file, grain size distribution, a digital elevation model (DEM) representing initial surface topography, a DEM representing the lower limit of erosion, and nearly 30 other parameters related to model optimisation, vegetation growth, hydrology, and slope processes. As the precipitation file is read, the model routes water over the grid of cells, preferentially eroding finer grained soil and depositing coarser grained soil according to either the Einstein (1950) or Wilcock and Crowe (2003) equations. For each time step, the model adjusts the topography accordingly, calculating the water level, grain size distribution, and elevation of each cell, then uses this information as a starting point for the next time step or iteration. When there are no changes occurring, or no precipitation falling CAESAR-Lisflood speeds up; correspondingly, when substantial changes occur the model slows down.

The CAESAR-Lisflood LEM is discussed in greater detail in (Coulthard et al., 2013). It has been extensively documented, calibrated to historic climates in Australia, Europe, and the UK, and results evaluated against those from the SIBERIA LEM, which uses drastically different input parameters (Coulthard \& van de Wiel 2017; Hancock et al. 2010, 2011, 2015; Lowry et al. 2013).

\subsubsection{Stress testing}

For this research, simulations were run using the Einstein-Brown equation due to the small and mostly uniform particle size typical of the CST collected and measured (Slingerland et al. 2018c). A 15-year hourly precipitation record was attained from the AOS region, quality controlled, and looped to create a 50-year record. Every five years, one 24-hour probable maximum precipitation (PMP) event (calibrated to the AOS region) was inserted using a triple-peak distribution (Dick \& Ghavasieh, 2015). This 50-year precipitation dataset was applied to all five dam designs in the stress testing exercise. The model applied a dampening effect to erosion as vegetation 'grew' to full maturity over 24 years, as outlined in Slingerland et al. (2018a).

The overall height, length, and basal channel width are based on typical AOS tailings dam dimensions; however, the five designs are entirely fictional. The dam designs use the same overall dimensions in each case but different topography between high and low points. Designs were generated in AutoCAD Civil3D and 
converted into ACSII format using ArcGIS. Results were in the form of DEMs representing final topography and elevation change and were analysed qualitatively (including use of geomorphic descriptors) with respect to soil loss, maintenance requirements etc. as well as quantitatively with respect to soil loss, denudation rates, and other statistical descriptors of the changes that occurred as a result of the stress test.

\section{Results and discussion}

Gully development on tailings dams poses a few main threats: the first is that gullies will extend below the reclamation cover installed and tailings will be exposed, the second is that gully depth will be such that the geotechnical stability of the dam itself is compromised. A third, less catastrophic but still important, concern is that maintenance will be so extensive in effort or time frame that it is considered an ongoing liability and is therefore not able to be granted a certificate of reclamation completion. In this case the mine owner is liable to maintain for as long as is necessary.

Geomorphic alterations to the dam designs were evaluated using both qualitative and quantitative methods following the 50-year simulated stress test. Timing of the simulations was not intended to be representative of any reality-based scenario, but to subject the designs to heavy precipitation-induced weathering. Therefore, only final form was assessed, despite the LEM's additional capabilities. Congruence between model predictions and corresponding measured sediment loss, gully sizing, and calculated water discharge, has been previously documented for the AOS (Slingerland 2019), therefore model outputs are considered to provide an evidence-based, relative estimation of dam degradation. Due to the non-realistic precipitation pattern used to drive this model, the results from this particular study are evaluated on a relative basis to one another and have not been put through a traditional 'validation' process.

\subsection{Qualitative geomorphology}

A visual assessment of the DEMs following stress testing indicates that each of the dam designs was impacted negatively to some degree (Figure 4). Only the 'platform-bank' and 'directed flow' designs produced a single gully that led to concentrated deposition of the eroded sediment in the basal channel. The 'directed flow' design produced a highly branching gully while the 'platform-bank' design produced predominantly one large gully with one small branch. The other three dam designs produced more widespread distribution of gullies across the full width of the dam, which led to a correspondingly widespread distribution of sediment deposited in the basal channel. The importance of erosional form (widespread or concentrated) has to do mostly with maintenance. Single, large gullies are easier to watch for as their locations may be expected and the extent of maintenance/restoration is concentrated; however, very deep gullies may lead to stability concerns in extreme circumstances and can create a challenge to restoring topography with small equipment. Shallower, widespread gullying can impede revegetation efforts, be excessively time consuming, and costly due to the area covered. Both scenarios clearly have unique maintenance implications.

The 'platform-bank' design generated much deeper gullies and gullies extended to a higher overall elevation than all other designs. The 'catena' design had a similarly even distribution of gullies to the 'constant slope' base case; however, gullies in the 'catena' design did not extend to as high an elevation and eroded sediment was deposited on the elongated lower portion of the slope. This reduced sediment loading within the basal channel, but also has the potential to bury vegetation planted at lower elevations.

While the 'directed flow' and 'armoured directed flow' dam designs had identical surficial topography, a $50 \mathrm{~m}$ wide strip down the centre of the armoured version was erosion resistant. At the end of the stress testing the two designs appeared quite differently from one another: the 'directed flow' design as previously discussed had one branching gully down the centre, while the 'armoured' version had two gullies formed down either side of the $50 \mathrm{~m}$ erosion-resistant strip, and small gullies distributed across the remaining slopes. This false armouring approach does not provide a perfect representation of how armouring functions, as it does not allow for infiltration through the $50 \mathrm{~m}$ wide strip; however, similar consequences have been noted in the field at several sites. In particular, this demonstrates that a refined, site-specific, and flexible topographic design may be capable of reducing gully erosion to a greater degree than rigid, or highly 'engineered', dam designs. 
(a)

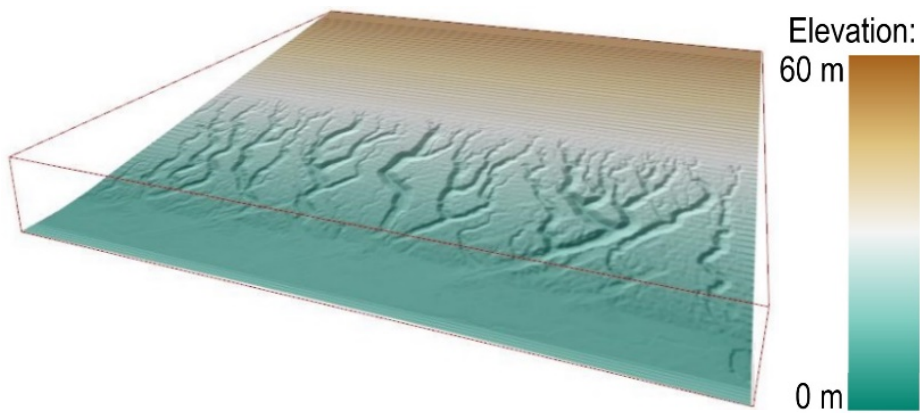

(b)
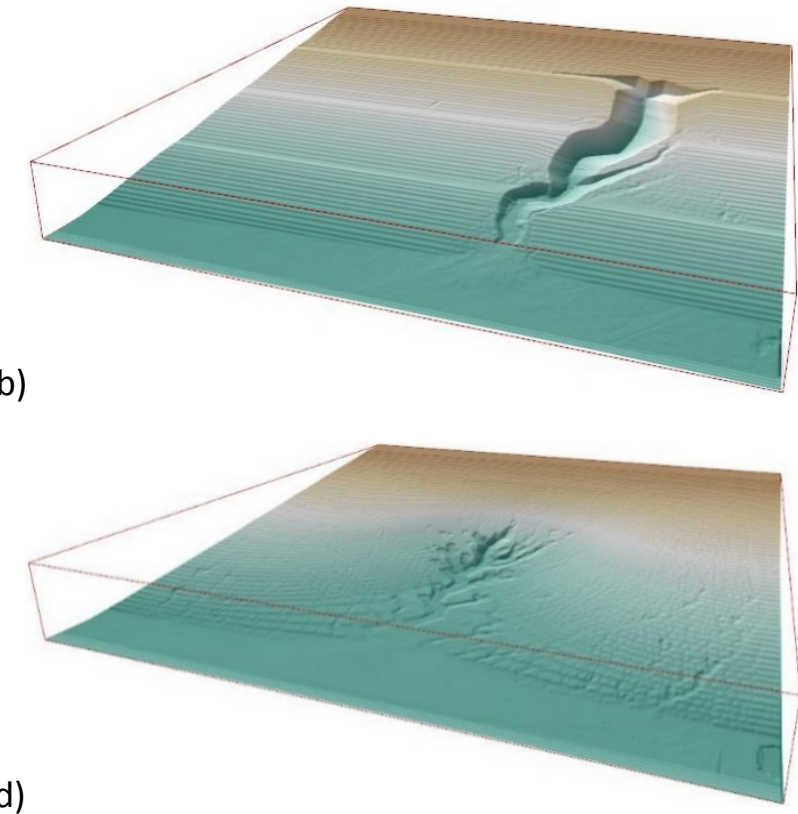

(c)
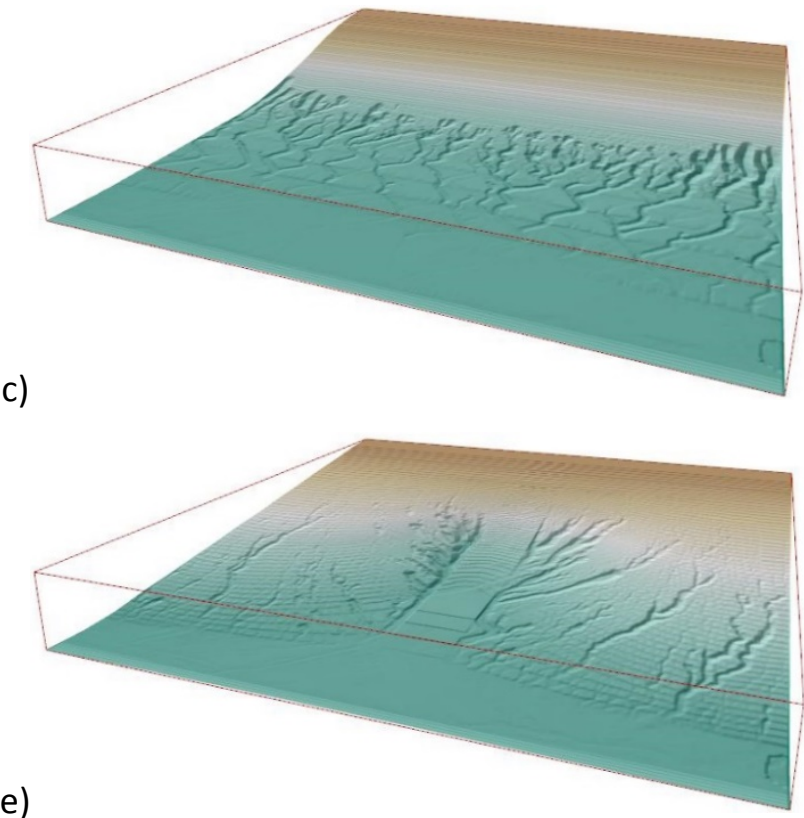

Figure 4 Dam designs following stress testing, shown in three dimensions (with colour ramp representing elevation): (a) constant slope, (b) platform-bank, (c) catena, (d) directed flow, and (e) armoured directed flow

\subsection{Quantitative geomorphology}

Mean elevation change, maximum depth of erosion, total soil loss, and standard deviation of elevation changes are used to better understand the changes that took place to the dam slope during stress testing. Similarly, mean elevation change, maximum depth of deposition, total soil added, and standard deviation of elevation changes are used to better understand the changes to the basal channel during stress testing. Table 1 summarises these changes for all five dam designs.

While the original concept for a 'platform-bank' dam design historically stemmed from the desire to reduce erosion on the traditional 'constant slope' designs using an 'USLE' approach, we see that without maintenance the 'platform-bank' dam design actually leads to substantially more soil loss than what occurred on the 'constant slope' design, or any of the other dam designs. The maximum depth of erosion attained on the 'platform-bank' design was over three times deeper than that for the 'constant slope' and 'catena', and more than double the maximum depth of either of the directed flow designs. The 'constant slope' design was second in terms of total soil loss. While much of the 'platform-bank' design was free from significant erosion, the single gully it did generate is of concern with respect to dam stability. The widespread but comparatively shallow erosion evident in the 'constant slope' design is more likely to cause challenges to revegetation and increased maintenance, but it may also threaten the efficacy of cover systems without ongoing maintenance. With respect to deposition in the basal channel, the 'platform-bank' design had the greatest total soil volume added and the highest maximum depth of deposition of all dam designs; the 'constant slope' came in second in these categories. From this precursory evaluation based on soil loss and depth of erosion, the 'constant 
slope' and 'platform-bank' designs performed the worst of all designs tested. The basal channel was nearly $50 \mathrm{~m}$ wide and three metres deep initially; however, nearly four metres of soil was deposited at the base of the channel from the gully on the 'platform-bank' design. This depth of soil was not consistent across the full width but does create significant narrowing of the channel and could potentially lead to overflow and flooding.

Table 1 Summary of elevation changes to the dam slopes and basal channel as a result of stress testing. Units are in metres unless noted otherwise

\begin{tabular}{lccccc}
\hline & $\begin{array}{c}\text { Constant } \\
\text { slope }\end{array}$ & $\begin{array}{c}\text { Platform } \\
\text {-bank }\end{array}$ & $\begin{array}{c}\text { Catena } \\
\text { Dam slope }\end{array}$ & $\begin{array}{c}\text { Directed } \\
\text { flow }\end{array}$ & $\begin{array}{c}\text { Armoured } \\
\text { directed flow }\end{array}$ \\
\hline Maximum depth of erosion & 7.45 & 23.78 & 7.64 & 9.88 & 9.55 \\
Total soil loss $\left(\mathrm{m}^{3}\right)$ & 71,840 & 132,030 & 57,830 & 29,990 & 48,078 \\
Mean elevation change & -0.17 & -0.37 & -0.15 & -0.05 & -0.10 \\
Standard deviation of elevation changes & 0.98 & 2.65 & 0.79 & 0.68 & 0.81 \\
& Basal channel & & & \\
Maximum depth of deposition & 2.43 & 3.79 & 1.13 & 1.55 & 1.85 \\
Total soil added (m ${ }^{3}$ ) & 28,830 & 39,110 & 19,350 & 16,380 & 23,640 \\
Mean elevation change & +0.68 & +0.92 & +0.46 & +0.39 & +0.56 \\
Standard deviation of elevation changes & 0.77 & 0.95 & 0.39 & 0.46 & 0.59 \\
\hline
\end{tabular}

The 'catena' design produced the third greatest volume of soil loss, but only a moderate amount of this soil was deposited in the basal channel. This corresponds to visual observations of deposition patterns whereby much of the soil was deposited on the shallow dam slope prior to entering the basal channel. This design had the lowest maximum depth of basal channel deposition, both due to the shape of the dam slope as well as the widespread distribution of gullies across the length of dam. One concern with respect to the 'catena' design is the maximum slope permitted in the initial design: with a well graded material slopes of $3 \mathrm{H}: 1 \mathrm{~V}$ are commonly constructed without slope failure or high erosion rates developing, however sand tailings are typically poorly graded with a very fine and narrow particle size distribution such that the maximum slope would need to be determined on a site-specific basis. This should be done regardless of the surficial capping material in order to achieve a conservative result.

With respect to the 'directed flow' and 'armoured directed flow' designs, they both produced similar maximum depths of erosion and low mean elevation change; however, the unarmoured version produced much less soil loss from the slope and deposition in the basal channel. In addition to these differences, the standard deviation of elevation changes between the initial and final dam slope topography is lowest for the unarmoured 'directed flow' design, indicating that less overall variation exists. While both of these directed flow dam designs performed better than any of the others, it is notable that the armoured version produced substantially more soil loss and more widespread soil loss relative to its unarmoured counterpart, leading to greater soil volumes added to the basal channel and the need for greater maintenance requirements.

\subsection{Additional considerations}

Overall, the 'directed flow' dam design performed best throughout the stress test: it generated the lowest volume of total soil loss and mean elevation change. The predictability of the gully formation location and the relative ease of repairing a single location as compared to a large area to be repaired is also advantageous. While this simulation did not adjust parameters for altered vegetation distribution across the dam slopes, it is likely that larger and denser vegetation would grow down the central drainage pathway in the 'directed 
flow' design, due to increased moisture content. This additional vegetation is likely to slow the flow of water and reduce surface erosion. Therefore, it is likely that the single, branching gully that developed on the 'directed flow' dam design would be reduced or fail to develop whatsoever. This benefit would not be seen in the armoured 'directed flow' design, should it be installed in reality, because armouring impedes vegetation growth.

The methods used to mimic large-diameter rip-rap within this study are not a perfect replica and therefore it is not possible to definitively conclude whether various forms of armouring are beneficial or not; however, the gullying produced by CAESAR-Lisflood in this stress test is consistent with field observations and reports from other researchers. Design of rip-rap erosion mitigation is plagued by several challenges according to Walters (1982), including: poor precipitation event and corresponding flood magnitude estimation (particularly in consideration of climate change), poor estimation of scour forces, and poor rock durability over long time frames (Toy \& Hadley 1987). In consideration of the many variables at play and consequences of long-term maintenance over the vast area covered in dam slopes in the AOS, a more flexible design may be prudent. Rip-rap channels do not allow for natural flow of material, such that deepening, lateral adjustment, and natural rejuvenation are impeded. It would also be beneficial in the future to adjust the CAESAR-Lisflood LEM such that multiple grain size distributions are possible, and armouring can be more accurately simulated in the models.

With respect to constructability, the more naturally-shaped designs ('catena', 'directed flow', and 'armoured directed flow') are undoubtedly more challenging than the traditional designs. Construction would require skilled professionals and likely the use of GPS-guided machinery; however, these people and this technology exists, and are readily employed on waste rock dumps and non-mining-related landforms. The higher cost is likely to be minimal when factored into the per barrel cost of oil, and lower maintenance costs post-closure would offset this over the life-of-mine.

\section{Conclusion}

Over the last 50 years or so the surficial topography built into tailings dams has evolved. The industry has migrated from a heavily controlled form and approach towards considerations that reflect the long-term liability that ongoing maintenance place on a mining company. In some instances, accommodation is made for flattening of dam slopes at closure; however, few oil sands mines have the space to do this, and it has been demonstrated that flattening of CST slopes does not reduce the likelihood of gully erosion from developing (Slingerland et al. 2018c). The concept of 'designing with nature' was introduced by McHarg in 1969 and seeks to change the way engineers and planners think about natural forces, such that nature is respected as an ally and a force to be worked with rather than against. This research sought to stress test five fictional tailings dam slopes set in the AOS region. The results of this modelling work, while unexpected in some respects, appear to reinforce McHarg's ideology. In constructing sand landforms to remain safe and stable whilst the enduring forces of nature are applied, this research has demonstrated that a more natural form, unimpeded by rigid armouring, provides the highest resistance. Additionally, it is likely that the changes predicted through this LEM simulation work would be dampened in reality by the preferential growth of vegetation along the central drainage pathway.

\section{Acknowledgement}

The authors would like to thank the Natural Sciences and Engineering Research Council of Canada (NSERC), Alberta Innovates - Energy and Environmental Solutions, and Golder Associates Ltd. for their financial support of this research. The authors would also like to thank Professor Tom Coulthard for making the CAESARLisflood software freely accessible and for his timely feedback during early model parameterisation. 


\section{References}

Coulthard, T 2017, CAESAR-Lisflood 1.9b [data set] Zenodo, doi:http:doi.org/10.5281/zendod.321820.

Coulthard, TJ \& van de Wiel, MJ 2017, 'Modelling long term basin scale sediment connectivity, driven by spatial land use changes', Geomorphology, vol. 277, pp. 265-281, doi:10.1016/j.geomorph.2016.05.027.

Coulthard, TJ, Neal, JC, Bates, PD, Ramirez, J, Almeida, GAM \& Hancock, GR 2013, 'Integrating the LISFLOOD-FP 2D hydrodynamic model with the CAESAR model: Implications for modelling landscape evolution', Earth Surface Processes \& Landforms, vol. 38, no. 15, pp. 1897-1906, doi:10.1002/esp.3478.

DePriest, NC, Hopkinson, LC, Quaranta, JD, Michael, PR \& Ziemkiewicz, PF 2015, 'Geomorphic landform design alternatives for an existing valley fill in central Appalachia, USA: quantifying the key issues', Ecological Engineering, vol. 81, pp. 19-29, doi:10.1016/j.ecoleng.2015.04.007.

Dick, W \& Ghavasieh, A 2015, 'A 24-h design storm for the fort McMurray region', Canadian Journal of Civil Engineering, vol. 42, no. 10 , pp. 747-755, doi:10.1139/cjce-2015-0034.

Eckels, R \& Bugosh, N 2010, 'Natural approach to mined land rehabilitation', Proceedings of the FIG Congress, International Federation of Surveyors, Copenhagen, pp. 1-17.

Einstein, HA 1950, 'The bed-load function for sediment transportation in open channel flows (Technical Bulletin No. 1026)', USDA Soil Conservation Service, US Department of Agriculture.

Haig, MJ 1979, 'Ground retreat \& slope evolution on regraded surface-mine dumps, Waunafon, Gwent', Earth Surface Processes, vol. 4, no. 2, pp. 183-189.

Hancock, G \& Willgoose, GR 2004, 'An experimental \& computer simulation study of erosion on a mine tailings dam wall', Earth Surface Processes \& Landforms, vol. 29, pp. 457-475.

Hancock, GR, Lock, RJ \& Willgoose, GR 2003, 'The design of post-mining landscapes using geomorphic principles', Earth Surface Processes \& Landforms, vol. 28, pp. 1097-1110.

Hancock, GR, Lowry, JBC \& Coulthard, TJ 2015, 'Catchment reconstruction - erosional stability at millennial time scales using landscape evolution models', Geomorphology, vol. 231, pp. 15-27.

Hancock, GR, Martin-Duque, JF \& Willgoose, GR 2019, 'Geomorphic design \& modelling at catchment scale for best mine rehabilitation - the Drayton Mine example (New South Wales, Australia)', Environmental Modelling \& Software, vol. 114, pp. 140-151.

Hancock, GR, Coulthard, TJ, Martinez, C \& Kalma, JD 2011, 'An evaluation of landscape evolution models to simulate decadal \& centennial scale soil erosion in grassland catchments', Journal of Hydrology, vol. 398, pp. 171-183.

Hancock, GR, Lowry, JBC, Coulthard, TJ \& Moliere, DR 2010, 'A catchment scale evaluation of the SIBERIA ad CAESAR landscape evolution models', Earth Surface Processes \& Landforms, vol. 35, pp. 863-875.

Hancock, GR, Lowry, JBC, Moliere, DR \& Evans, KG 2008a, 'An evaluation of an enhanced soil erosion \& landscape evolution model: A case study assessment of the former Nabarlek Uranium Mine, Northern Territory, Australia', Earth Surface Processes \& Landforms, vol. 33, pp. 2045-2063.

Hancock, GR, Crawter, D, Fityus, SG, Chandler, J \& Wells, T 2008b, 'The measurement \& modelling of rill erosion at angle of repose slopes in mine spoil', Earth Surface Processes \& Landforms, vol. 33, pp. 1006-1020.

Hancock, GR, Evans, KG, Willgoose, GR, Moliere, DR, Saynor, MJ \& Lock, RJ 2000, 'Medium-term erosion simulation of an abandoned mine site using the SIBERIA landscape evolution model', Australian Journal of Soil Research, vol. 38, pp. 249-263.

Kemp, A, Taylor, I \& O'Kane, M 2016, 'Waste landform cover system \& geometrical design - integration with waste placement \& landform optimisation approach', in AB Fourie \& M Tibbett (eds), Proceedings of the 11th International Conference on Mine Closure, Australian Centre for Geomechanics, Perth, pp. 135-142.

Lowry, JBC, Coulthard, TJ \& Hancock, GR 2013, 'Assessing the long-term geomorphic stability of a rehabilitated landform using the CAESAR-Lisflood landscape evolution model', in AB Fourie, M Tibbett \& C Digby (eds), Proceedings of the Eighth International Seminar on Mine Closure, Australian Centre for Geomechanics, Perth, pp. 611-624.

Lowry, JBC, Narayan, M, Hancock, GR \& Evans, KG 2019, 'Understanding post-mining landforms: Utilising pre-mine geomorphology to improve rehabilitation outcomes', Geomorphology, vol. 328, pp. 93-107.

Martin-Duque, JF, Sanz, MA, Bodoque, JM, Lucia, A \& Martin-Moreno, C 2010, 'Restoring earth surface processes through landform design, A 13-year monitoring of a geomorphic reclamation model for quarries on slopes', Earth Surface Processes \& Landforms, vol. 35, pp. 531-548.

McHarg, IL 1969, Design with nature, Natural History Press, Garden City.

McKenna, G \& Dawson, R 1997, 'Closure planning practice \& landscape performance at 57, Canadian \& US mines, Proceedings of the 21st Annual British Columbia Mine Reclamation Symposium, Cranbrook, BC, pp. 74-87.

Nicolau, J 2003, 'Trends in relief design \& construction in opencast mining reclamation', Land Degradation \& Environment, vol. 14, pp. 215-226.

Oil Sands Tailings Dam Delicensing Committee 2014, 'De-licensing of oil sands tailings dams technical guidance document', Calgary.

Rowell, MJ 1977, 'Revegetation \& management of tailings sand slopes from tar sand extraction: 1978 results', Environmental Research Monograph 1977-4, Syncrude Environmental Research Monograph, Edmonton.

Sawatsky, LF \& Beckstead, GRE 1996, 'Geomorphic approach for design of sustainable drainage systems for mineland reclamation', International Journal of Surface Mining, Reclamation \& Environment, vol. 10, no. 3, pp. 127-129.

Sawatsky, L \& Beersing, A 2014, 'Configuring mine disturbed landforms for long-term sustainability, Proceedings of Mine Closure Solutions 2014, Ouro Preto, Minas Gerais, pp. 1-13. 
Sawatsky, L, McKenna, G, Keys, MJ \& Long, D 2000, 'Towards minimising the long-term liability of reclaimed mine sites', Land Reconstruction \& Management (vol. 1), Rotterdam, The Netherlands: AA Balkema, pp. 21-36.

Slingerland, N 2019, 'Geomorphic landform design \& long-term assessment of tailings storage facilities in the Athabasca oil sands', $\mathrm{PhD}$ dissertation, University of Alberta, Edmonton.

Slingerland, N, Beier, NA \& Wilson, GW 2018a, 'Landscape evolution modelling of large sand tailings dams', in C Drebenstedt, F von Bismarck, AB Fourie \& M Tibbett, Proceedings of the 12th International Conference on Mine Closure, Leipzig, Germany. pp. 341-348.

Slingerland, N, Beier, NA \& Wilson, GW 2019, 'Oil sands tailings storage facilities: design considerations for ease of closure', CIM Journal, vol. 10(2), pp. 1-12, https://doi.org/10.15834/cimj.2019.7

Slingerland, N, Isidoro, A, Fernandez, S \& Beier, NA 2018b, 'Geomorphic analysis for tailings dam design in consideration of a 1000year closure design life', Proceedings of the 2nd International Congress on Planning for Closure of Mining Operations, Santiago, Chile, pp. 1-9.

Slingerland, N, Sommerville, A, O'Leary, D \& Beier, NA 2018c, 'Identification \& quantification of erosion on a sand tailings dam', Geosystem Engineering [online], pp. 1-15, doi:10.1080/12269328.2018.1538823.

Surface Mining Control \& Reclamation Act (SMCRA) 1977, Surface Mining Control \& Reclamation Act of 1977, Pub. L 95-87, Stat. 445, Washington, DC.

Toy, TJ \& Black, JP 2000, 'Topographic reconstruction: the theory \& practice', Agronomy, vol. 41, pp. 41-76.

Toy, TJ \& Chuse, WR 2005, 'Topographic reconstruction: a geomorphic approach', Ecological Engineering, vol. 24, pp. 29-35.

Toy, TJ \& Hadley, RF 1987, Geomorphology \& Reclamation of Disturbed Lands, Academic Press, Orlando, Florida.

Walters, WH 1982, 'Rock riprap design methods \& their applicability to long-term protection of uranium mill tailings impoundments, NUREG/CR-2684, (PLN-4252), Nuclear Regulatory Commission, Richland.

Wilcock, PR \& Crowe, JC 2003, 'Surface-based transport model for mixed-size sediment', Journal of Hydraulic Engineering, vol. 129, no. 2 , pp. 120-128. 
